\title{
PERBANDINGAN LAPIS PERKERASAN LENTUR DENGAN LAPIS PERKERASAN KAKU PADA RUAS JALAN CIANJUR-SUKABUMI KM.BDG 67+720 s/d 80+257 KABUPATEN CIANJUR
}

\author{
Yudi Sekaryadi \\ Ida Dwi Ratri \\ Jurusan Teknik Sipil Fakultas Teknik \\ Unversitas Suryakancana Cianjur
}

\begin{abstract}
A B S T R AK
Jalan merupakan suatu konstruksi yang berfungsi sebagai prasarana perhubungan darat yang memegang peranan penting dalam kehidupan manusia. Dengan adanya jalan yang memadai dapat memperlancar distribusi barang dan jasa sehingga kebutuhan pemakai jalan dapat terpenuhi. Mengamati kondisi existing jalan perkerasan yang sudah mulai rusak pada ruas jalan CianjurSukabumi, maka perlu di adakannya pemikiran untuk memperbaiki jalan tersebut untuk memperoleh kenyamanan dan ke amanan bagi pengguna jalan tersebut.

Pada tugas akhir ini dicoba di ruas jalan Cianjur-Sukabumi dengan STA 67+720 s/d 80+257. Dengan nilai CBR yang mewakili yaitu sebesar 3\% didapat menggunakan cara MAK (Metode Analisa Komponen). Untuk ketebalan perkerasan lentur di segmen jalan tersebut dengan CBR 3\% didapat Asphalt concrete $-\mathrm{WC}(\mathrm{MS} .744)=4 \mathrm{~cm}, A C-B C=6 \mathrm{~cm}$ untuk lapis tambahan. Apabila diamati secara kasat mata jumlah kendaraan yang melintasi jalan tersebut cukup tinggi, mengingat jumlah LHR (Lalu Lintas Harian Rata-rata). Itu berarti semakin besar jumlah LHR semakin tebal pula lapisaan perkerasan lentur yang dibutuhkan., maka dari itu memerlukan data lalu lintas yang ada, adapun data lalu lintas harian rata-rata yang didapat dari hasil survey langsung yaitu sebesar $7405 \mathrm{kend} /$ hari dari dua lajur. Mengingat kondisi jalan tersebut yang berlubang akibat LHR yang cukup tinggi, maka perlu adanya upaya untuk mengganti perkerasan lentur (Flexibel Pavement) dengan perkerasan kaku (Rigid Pavement). Sehingga didalam perhitungan diperoleh tebal perkerasan kaku yaitu $27 \mathrm{~cm}$ (sesuai dengan peraturan Dinas Provinsi Jawa Barat). Dan untuk rencana anggaran biaya untuk pekerjan perkerasan lentur didapat Rp 43.721.174.775 sedangkan untuk perkerasan kaku di dapat Rp 59.412.754.817.
\end{abstract}

\section{Kata kunci : jalan, lentur, kaku, lapis tambahan, rencana anggaran biaya}

\section{A. Pendahuluan}

Jalan merupakan suatu konstruksi yang berfungsi sebagai prasarana perhubungan darat yang memegang peranan penting dalam kehidupan manusia. Dengan adanya jalan yang memadai dapat memperlancar distribusi barang dan jasa sehingga kebutuhan pemakai jalan dapat terpenuhi. Dengan meningkatnya perkembangan sektor perindustrian di Cianjur dan Sukabumi, maka meningkat pula kebutuhan akan sarana dan prasarana transportasi jalan yang baik dan aman tetapi mempunyai nilai guna dan manfaat dari segi ekonomis yang akan datang.

\section{B. Metode Penelitian}

Jenis penelitian merupakan metode ekperimen. Penelitian yang dilakukan, yang pertama menentukan lokasi yang akan diteliti agar mendapatkan data yang diinginkan dan selanjutnya pengumpulan. Pengumpulan data dibagi menjadi dua bagian, yaitu : data primer, dimana data primer yaitu data yag didapatkan dari hasil survey langsung seperti data volume kendaraan (LHR). Data sekunder, dimana data sekunder merupakan yang diperoleh dari pihak lain atau dinas terkait dalam bentuk dokumen atau dalam betntuk publikasi.

Jalan Cianjur-Sukabumi merupakan salah satu jalan yang digunakan untuk menunjang hal tersebut, kondisi tanah pada ruas jalan 
Cianjur-Sukabumi sangatlah rentan gerakan tanah tinggi sehingga jalan tersebut mengalami kerusakan dan tanpa adanya upaya lebih lanjut dapat mengakibatkan permasalahan lalu lintas. Perencanaan peningkatan jalan merupakan salah satu upaya untuk mengatasi permasalahan lalu lintas di ruas jalan Cianjur-Sukabumi. Sehingga Pemerintah Provinsi Jawa Barat melaksanakan perkerasan lentur (flexible pavement).

Data sekunder diperoleh dari Dinas Binamarga Provinsi Jawa Barat, Dinas Pengembangan Sumber Daya Air dan Pembangunan dan Data Statistik Provinsi Jawa Barat. Dalam penelitian ini data sekunder yang diperlukan meliputi : Data iklim (curah hujan) per tahun, data CBR tanah dasar, data tebal nominal rancangan campuran aspal dan toleransi, data statistik pertumbuhan lalu lintas. Metode analisis, dimana metode ini merangkum sejumlah data yag didapatkan dengan mengacu pada Metode Analisis Komponen untuk perkerasan lentur dan SNI Pd T-14-2003 Jalan Beton Semen.

\section{Hasil Penelitian dan Pembahasan}

\section{1) Perencanaan Perkerasan Lentur}

Perencanaan Perkerasan Lentur dilakukan dengan menggunakan SNI 1732 -1989-F "Tata Cara Perencanaan Tebal Perkerasan Lentur Jalan Raya Dengan Metoda Analisa Komponen".

Data sekunder yang diperoleh :

Data perencanaan :

a. Tebal perkerasan untuk jalan :2/2 UD

b. Data lalu lintas : Tahun 2017

c. Umur rencana : 10 tahun,

d. pertumbuhan lalu lintas umur rencana 10 tahun (i) :

- Kendaraan Ringan, truck 2as : $15 \%^{10}$

- Bus, truck 3as, truck gandeng : 8\% ${ }^{10}$

e. Faktor Regional (FR) tabel $2.8: 1,0$

- Kelandaian jalan $(3,4 \%-7,6 \%): 5 \%$

- Persentase kendaraan berat(\%): > $30 \%$

- Curah hujan $405 \mathrm{~mm} /$ tahun : < 900 $\mathrm{mm} / \mathrm{th}$

Dan material lapis perkerasan terdiri dari lapis permukaan, lapis pondasi dan lapis pondasi bawah dengan material secara berurutan adalah sebagai berikut :

1) Asphalt concrete - WC
2) Asphalt concrete-Base,

3) Base Agregat A CBR

4) Sub base agregat B CBR

Tabel 4.1 Data Lalu lintas Harian Rata-rata

\begin{tabular}{|l|c|c|}
\hline Cianijur-Sukabumi & & \\
\hline Jenis Kendaraan & Beban Sumbu & Jumlah Kendaraan Perhari \\
\hline Kendaraan Ringan & $(1+1)$ & 2958 kend/hari \\
\hline Bus & $(3+5)$ & 70 kend/hari \\
\hline Truk 2 as kecil & $(2+4)$ & 27 kend/hari \\
\hline Truk 2 as 13 ton & $(5+8)$ & $692 \mathrm{kend} /$ hari \\
\hline Truk 3 as & $(6+14)$ & $79 \mathrm{kend} /$ hari \\
\hline Truk Gandeng & $(6+14+5+5)$ & 9 kend/hari \\
\hline & $\sum$ LHR $=$ & $3835 \mathrm{kend} /$ hari \\
\hline
\end{tabular}

Tabel 4.2 Data Lalu lintas Harian Rata-rata

\begin{tabular}{|l|c|c|}
\hline Sukabumi-Cianjur & & \\
\hline Jenis Kendaraan & Beban Sumbu & Jumlah Kendaraan Perhari \\
\hline Kendaraan Ringan & $(1+1)$ & 2792 kend/hari \\
\hline Bus & $(3+5)$ & $63 \mathrm{kend} /$ hari \\
\hline Truk 2 as kecil & $(2+4)$ & $22 \mathrm{kend} /$ hari \\
\hline Truk 2 as 13 ton & $(5+8)$ & $613 \mathrm{kend} /$ hari \\
\hline Truk 3 as & $(6+14)$ & $71 \mathrm{kend} /$ hari \\
\hline Truk Gandeng & $(6+14+5+5)$ & $9 \mathrm{kend} /$ hari \\
\hline & $\sum$ LHR $=$ & 3570 kend/hari \\
\hline
\end{tabular}

Tabel 4.3 Data Lalu lintas Harian Rata-rata

\begin{tabular}{|l|c|c|}
\hline Total Kendaraan di Dua Lajur & \\
\hline Jenis Kendaraan & Beban Sumbu & Jumlah Kendaraan Perhari \\
\hline Kendaraan Ringan & $(1+1)$ & 5750 kend/hari \\
\hline Bus & $(3+5)$ & 133 kend/hari \\
\hline Truk 2 as kecil & $(2+4)$ & 49 kend/hari \\
\hline Truk 2 as 13 ton & $(5+8)$ & 1305 kend/hari \\
\hline Truk 3 as & $(6+14)$ & 150 kend/hari \\
\hline Truk Gandeng & $(6+14+5+5)$ & 18 kend/hari \\
\hline & $\sum$ LHR $=$ & 7405 kend/hari \\
\hline
\end{tabular}

Tabel 4.4 LHR pada akhir tahun ke-10 dengan rumus : $\operatorname{LHR}_{10}(1+\mathrm{i})^{10}$

\begin{tabular}{|c|c|c|}
\hline Jenis Kendaraan & Beban Sumbou & Kend hari' 2 arah $(1+1)$ n \\
\hline Kendaraan Ringan & $(1+1)$ & $=5750(1+15 \%)^{10}=23.261 .95$ Kend hart \\
\hline Bus & $(3+5)$ & $=133(1+8 \%)^{10}=287$ Kend hati \\
\hline Truk 2 as kecll & $(2+4)$ & $=49(1+15 \%)^{10}=198,23$ Kend hat' \\
\hline Truk 2 as 13 ton & $(5+8)$ & $=1305(1+8 \%)^{10}=2817$ Kend hart \\
\hline Truk 3 as & $(6+14)$ & $=150(1+8 \%)^{10}=323$ Kendhari \\
\hline Truk Gandeng & $(6+14+5+5)$ & $=18(1+8 \%)^{10}=38$ Kend hari \\
\hline
\end{tabular}




\section{2) Perhitungan Angka Ekivalen (E)}

Perhitungan angka ekivalen (E) untuk masing-masing jenis kendaraan dengan asumsi pada konfigurasi beban ganda yaitu :

a. Perhitungan Angka Ekivalen (E)

Menghitung angka ekivalen (E) beban sumbu kendaraan dapat dilihat pada daftar tabel 2.7 (BAB II Landasan Teori, hal. 17) :

Tabel 4.5 Hasil Perhitungan Angka Ekivalen

\begin{tabular}{|l|c|l|}
\hline Jenis Kendaraan & Beban Sumbu & \multicolumn{1}{|c|}{ Angka Ekivalen } \\
\hline Kendaraann Ringant & $(1+1)$ & $=0,0002+0,0002=0,0004$ \\
\hline Buls & $(3+5)$ & $=0,0183+0,141=0,1593$ \\
\hline Truk 2 as kecl & $(2+4)$ & $=0,0036+0,0577=0,0613$ \\
\hline Truk 2 as 13 ton & $(5+8)$ & $=0,1410+0,9238=1,0648$ \\
\hline Truk 3 as & $(6+14)$ & $=0,2923+0,7452=1,0375$ \\
\hline Truk Gandeng & $(6+14+5+5)$ & $=0,0252+0,9820+0,0121+0,0121=1,0312$ \\
\hline
\end{tabular}

b. Perhitungan Lintas Ekivalen Permulaan (LEP)

$$
\mathbf{L E P}=\sum_{j=1}^{n} \quad \operatorname{LHR}_{i} x \mathrm{C}_{j} x \mathrm{E}_{j}
$$

Sesuai dengan rumus tersebut untuk koefisien distribusi kendaraan (C) dan angka ekivalen (E) beban sumbu kendaraan dapat dilihat pada daftar tabel 2.6 dan 2.7 (BAB II Landasan Teori, hal. 16 dan 17) :

Tabel 4.6 Hasil Perhitungan Lintas Ekivalen Permulaan (LEP)

\begin{tabular}{|l|c|l|}
\hline Jenis Kendaraan & Beban Sumbu & \multicolumn{1}{c|}{ LHRj $\times$ Cj $\times$ Ej } \\
\hline Kendaraan Ringan & $(1+1)$ & $=5750 \times 0,5 \times 0,0004=1,15$ \\
\hline Bus & $(3+5)$ & $=133 \times 0,5 \times 0,1593=10,5934$ \\
\hline Truk 2 as kecil & $(2+4)$ & $=49 \times 0,5 \times 0,0613=1,50185$ \\
\hline Truk 2 as 13 ton & $(5+8)$ & $=1305 \times 0,5 \times 1,0648=694,782$ \\
\hline Truk 3 as & $(6+14)$ & $=150 \times 0,5 \times 1,0375=77,8125$ \\
\hline Truk Gandeng & $(6+14+5+5)$ & $=18 \times 0,5 \times 1,0312=9,2808$ \\
\hline & LEP & $\sum=795,12$ \\
\hline
\end{tabular}

c. Perhitungan Lintas Ekivalen Akhir (LEA)

$$
\mathbf{L E A}=\sum_{j=1}^{n} \operatorname{LHR}_{j}(1+i)^{\mathrm{UR}} x \mathrm{C}_{j} x \mathrm{E}_{j}
$$

Untuk perhitungan LEA dengan umur rencana 10 tahun dan angka pertumbuhan lalu lintas sebesar 8\%, maka dihitung sesuai dengan rumus diatas untuk koefisien distribusi kendaraan (C) dan angka ekivalen
(E) beban sumbu kendaraan dapat dilihat pada daftar tabel 2.6 dan 2.7) :

Tabel 4.7 Hasil Perhitungan Lintas Ekivalen Akhir (LEA)

\begin{tabular}{|l|c|l|}
\hline Jenis Kendaraan & Beban Sumbu & LHRj $(1+1) U R \times$ C j $\times$ Ej \\
\hline Kendaraan Ringan & $(1+1)$ & $=23.261,95 \times 0,5 \times 0,0004=4,65239$ \\
\hline Bus & $(3+5)$ & $=287 \times 0,5 \times 0,1593=22,85955$ \\
\hline Truk 2 as kecil & $(2+4)$ & $=198,23 \times 0,5 \times 0,0613=6,07575$ \\
\hline Truk 2 as 13 ton & $(5+8)$ & $=2817 \times 0,5 \times 1,0648=1499,7708$ \\
\hline Truk 3 as & $(6+14)$ & $=323 \times 0,5 \times 1,0375=167,55625$ \\
\hline Truk Gandeng & $(6+14+5+5)$ & $=38 \times 0,5 \times 1,0312=19,5928$ \\
\hline & LEA & $\sum=1720,50$ \\
\hline
\end{tabular}

d. Perhitungan Lintas Ekivalen Tengah (LET)

$$
\begin{aligned}
\text { LET } & =\frac{\text { LEP }+ \text { LEA }}{2} \\
\text { LET } & =\frac{795,12+1720,50}{2} \\
& =1257,8
\end{aligned}
$$

Berdasarkan rumus diatas, maka LET yang diperoleh adalah LET $=1255,8$

$$
\begin{array}{ll}
\text { e. } & \text { Perhitungan Lintas Ekivalen Umur } \\
& \text { Rencana (LER) } \\
\text { LER } & =\text { LET } \times \text { FP } \\
\text { FP } & =\text { UR/10 } \\
\text { LER } & =1257,8 \times 10 / 10 \\
& =1257,8 \approx 1258
\end{array}
$$

\section{3) Perhitungan Daya Dukung Tanah (DDT) dan CBR Tanah}

Dalam menentukan nilai CBR tanah dasar ini yaitu dengan cara membuat grafik hubungan antara harga CBR dan presentase, nilai CBR yang mewakili adalah yang didapat dari angka presentase dengan cara menggunakan metode analisa komponen (MAK). Sesuai pada gambar 4.6 CBR yang mewakili didapat 3.

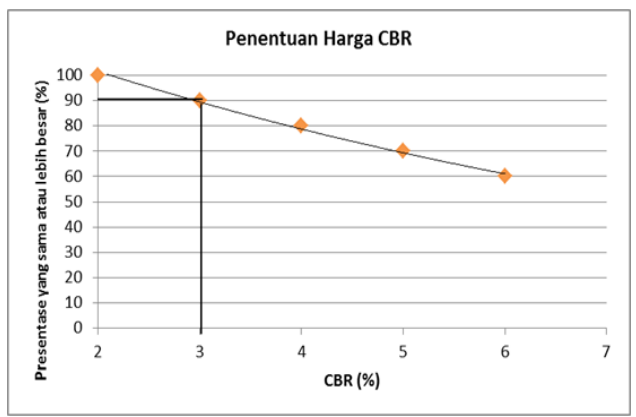


Gambar 4.8 Grafik CBR yang mewakili

$\mathrm{CBR}=3 \%$ dari KM.BDG STA $67+720 \mathrm{~s} / \mathrm{d}$ $80+257$

. Cara analitis :

DDT $=4,3 \times \log (\mathrm{CBR})+1,7$

$=4,3 \times \log (3 \%)+1,7=3,7 \%$

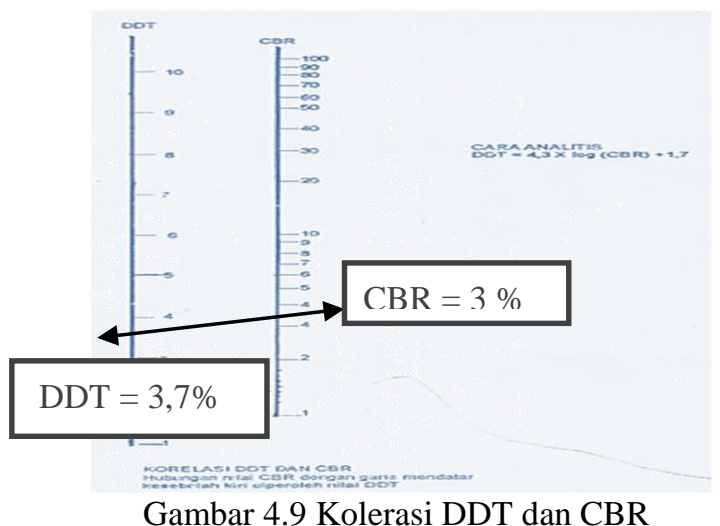

Gambar 4.9 Kolerasi DDT dan CBR

\section{4) Perhitungan Menentukan Indeks}

Permukaan (IP)

Indeks permukaan Akhir Umur Rencana $\left(\mathrm{IP}_{\mathrm{t}}\right)$ dengan pertimbangan faktor klasifikasi jalan dan (LER) pada daftar tabel 2.10 :
1) LER
: 1258
2) Klasifikasi Jalan: Jalan Arteri

Maka didapat $\mathrm{IP}_{\mathrm{t}}: 2,5$

Indeks Permukaan Awal Umur Rencana ( $\mathrm{IP}_{\mathrm{o}}$ ) sesuai dengan daftar tabel 2.11 (BAB II Landasan Teori, hal. 23) : Jenis permukaan (Laston) aspal beton, dengan roughness $\leq$ $1000 \mathrm{~mm} / \mathrm{km}$, maka IPo diambil $=>4$

\section{5) Perhitungan indeks tebal perkerasan yang diharapakan (ITP perlu $_{\text {) }}$}

Data Pendukung :

1. STA $67+720 \mathrm{~s} / \mathrm{d} 80+257$

$\begin{array}{lll}> & \text { CBR tanah dasar }: 3 \% \\ > & \text { DDT } & : 3,8 \% \\ > & \text { IPt } & : 2,5 \\ > & \text { IPo } & : 3,9 \\ > & \text { FR } & : 1,0 \\ > & \text { LER } & : 1258\end{array}$

Harga indeks tebal perkerasan diperoleh dengan menggunakan Lampiran 1 (1) LER $=1258 ;$ DDT $=3,8 ; \mathrm{FR}=1,0$ maka didapat ITP $=11,7$ (menggunakan nomogram).

\section{6) Perhitungan Susunan Perkerasan}

Direncanakan lapisan perkerasan sesuai daftar tabel 2.12 (BAB II Landasan Teori, hal. 24) koefisien kekuatan relatif :

a. Lapisan Permukaan: Laston $\left(\mathrm{a}_{1}\right)$ $=0,40$

b. Lapisan base (pondasi) batu pecah atas: Agregat A $\left(a_{2}\right)=0,14($ CBR 100\%)

c. Lapisan sub base (pondasi bawah) sirtu : Agregat B $\left(\mathrm{a}_{3}\right)=0,13(\mathrm{CBR} 70 \%)$

Diambil sesuai daftar tabel 2.12 batas-batas minimum tebal lapisan perkerasan.

Dan diambil tebal:

$>$ Laston (Ms. 744) $\mathrm{D}_{1}=10 \mathrm{~cm}$

$>$ Pondasi atas $\mathrm{D}_{2}=20 \mathrm{~cm}$

$>$ Pondasi bawah $\mathrm{D}_{3}=10 \mathrm{~cm}$

Kekuatan jalan baru :

$$
\begin{aligned}
& 70 \% \times 0,40 \times 10 \mathrm{~cm} \quad=2,8 \\
& 100 \% \times 0,14 \times 20 \mathrm{~cm} \quad=2,8 \\
& 70 \% \times 0,13 \times 10 \mathrm{~cm} \quad=0,91+ \\
& =6,51
\end{aligned}
$$

Menetapkan lapisan tambahan :

Kekuatan jalan lama :

a. Asphalt concrete $-\mathrm{WC}(\mathrm{MS} .744) 4 \mathrm{~cm}=$ $50 \%$ × 4 × $0,35=0,7$

b. Asphalt concrete - Base $6 \mathrm{~cm}=60 \% \mathrm{x}$ $6 \times 0,35=1,26$

c. Base Agregat A CBR $20 \mathrm{~cm}=70 \% \times 20$ x $0,14=1,96$

d. Sub base agregat $\mathrm{B}$ CBR $30 \mathrm{~cm}=90 \% \mathrm{x}$ $30 \times 0,13=3,51$

ITP ada $=7,34$

UR 10 Tahun :

$\Delta$ ITP $=$ ITP10-IT Pada $=11,7-7,43=5,27$

$0,40=4,27 . \mathrm{D} 1$

D1 $=10,6 \approx 10 \mathrm{~cm}$ Asbuton (MS.744).

7) Perencanaan Perkerasan Kaku

Diketahui data parameter perencanaan perkerasan kaku adalah sebagai berikut :

1. CBR tanah dasar pada STA $67+720 \mathrm{~s} / \mathrm{d}$ 80+257. CBR 3\%.

2. Ditentukan CBR tanah dasar rencana (efektif) : 8,2\% (BAB II Landasan Teori, gambar 2.17 hal. 30,

3. Kuat tarik lentur $\left(\mathrm{f}_{\mathrm{cf}}\right) \quad: 3,4 \mathrm{M}_{\mathrm{pa}}$

4. Bahu Jalan : ya

5. Ruji (dowel) : ya

6. Pertumbuhan lalu lintas (i) : $12 \% /$ thn

7. Umur rencana (UR) : 10 tahun

8. Direncanakan Perkerasan beton untuk jalan arteri dengan 2 lajur 2 arah tanpa median. 
9. Direncanakan perkerasan beton bersambung tanpa tulangan dengan ruji $\rightarrow$ (BBTT) .

10. Data lalu lintas harian rata-rata :

Tabel 4.10 Lalu lintas Harian Rata-rata

\begin{tabular}{|l|c|r|}
\hline \multicolumn{2}{|l|}{ Total Kendaraan diDua Lajur } & \multicolumn{1}{l|}{} \\
\hline Jenis Kendaraan & Beban Sumbu & Jumlah Kendaraan Perhari \\
\hline Kendaraan Ringan & $(1+1)$ & 5750 kend/hari \\
\hline Bus & $(3+5)$ & 133 kend/hari \\
\hline Truk 2 as kecil & $(2+4)$ & $49 \mathrm{kend} / \mathrm{hari}$ \\
\hline Truk 2 as 13 ton & $(5+8)$ & $1305 \mathrm{kend} / \mathrm{hari}$ \\
\hline Truk 3 as & $(6+14)$ & $150 \mathrm{kend} / \mathrm{hari}$ \\
\hline Truk Gandeng & $(6+14+5+5)$ & $18 \mathrm{kend} / \mathrm{hari}$ \\
\hline & $\sum$ LHR $=$ & $7405 \mathrm{kend} / \mathrm{hari}$ \\
\hline
\end{tabular}

\section{8) Langkah-langkah Perhitungan Tebal} Pelat

a. Analisis lalu lintas

Analisis Lalu lintas untuk perhitungan jumlah sumbu berdasarkan jenis dan beban kendaraan sesuai dengan SNI Pd T-14-2003 ; tabel 13 hal 36.

Tabel 4.11 Hasil Perhitungan Jumlah Sumbu Berdasarkan Jenis Dan Beban Kendaraan

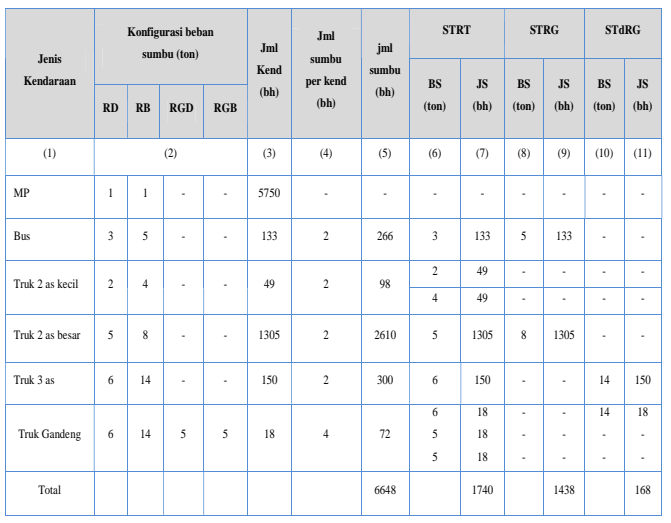

Keterangan $: \mathrm{RD}=$ roda depan, $\mathrm{RB}=$ roda belakang, RGD = roda gandeng depan, RGB = roda gandeng belakang, $\mathrm{BS}=$ beban sumbu, JS = jumlah sumbu, STRT = sumbu tunggal roda tunggal, STRG = sumbu tunggal roda ganda, STdRG = sumbu tandem roda ganda .

Jumlah sumbu kendaraan niaga (JSKN) selama umur rencana (10 tahun)

JSKN $=365 \times$ JSKNH $\times$ R

$$
=365 \times 6648 \times 17,55
$$

$=42.585 .425$

JSKN rencana $=\mathrm{C}$ (koefisien distribusi kendaraan) x JSKN

$$
\begin{aligned}
& =0,5 \times 42.585 .425 \\
& =21.292 .713
\end{aligned}
$$

Tabel 4.12 Faktor pertumbuhan lalu-lintas ( R)

\begin{tabular}{|c|c|c|c|c|c|c|}
\hline $\begin{array}{c}\text { Umur Rencana } \\
\text { (Tahun) }\end{array}$ & \multicolumn{5}{|c|}{ Laju Pertumbuhan (i) per tahun (\%) } \\
\cline { 2 - 7 } & $\mathbf{0}$ & $\mathbf{2}$ & $\mathbf{4}$ & $\mathbf{6}$ & $\mathbf{8}$ & $\mathbf{1 0}$ \\
\hline $\mathbf{5}$ & 5 & 5,2 & 5,4 & $\mathbf{5 , 6}$ & 5,9 & 6,1 \\
\hline 10 & 10 & 10,9 & 12 & 13,2 & 14,5 & 15,9 \\
\hline 15 & 15 & 17,3 & 20 & 23,3 & 27,2 & 31,8 \\
\hline 20 & 20 & 24,3 & 29,8 & 36,8 & 45,8 & 57,3 \\
\hline 25 & 25 & 32 & 41,6 & 54,9 & 73,1 & 98,3 \\
\hline 30 & 30 & 40,6 & 56,1 & 79,1 & 113,3 & 164,5 \\
\hline 35 & 35 & 50 & 73,7 & 111,4 & 172,3 & 271 \\
\hline 40 & 40 & 60,4 & 95 & 154,8 & 259,1 & 442,6 \\
\hline
\end{tabular}

Tabel 4.13 Jumlah lajur berdasarkan lebar

\begin{tabular}{|c|c|c|c|}
\hline \multirow{2}{*}{ Lebar perkerasan $\left(L_{p}\right)$} & \multirow{2}{*}{$\begin{array}{c}\text { Jumlah lajur } \\
\left(\mathrm{n}_{\mathrm{l}}\right)\end{array}$} & \multicolumn{2}{|c|}{ Koefisien distribusi } \\
\hline & & 1 Arah & 2 Arah \\
\hline $\mathrm{L}_{\mathrm{p}}<5,50 \mathrm{~m}$ & 1 lajur & 1 & 1 \\
\hline $5,50 \mathrm{~m} \leq \mathrm{L}_{\mathrm{p}}<8,25 \mathrm{~m}$ & 2 lajur & 0,7 & 0,5 \\
\hline $8,25 \mathrm{~m} \leq \mathrm{L}_{\mathrm{p}}<11,25 \mathrm{~m}$ & 3 lajur & 0,5 & 0,475 \\
\hline $11,23 \mathrm{~m} \leq \mathrm{L}_{\mathrm{p}}<15,00 \mathrm{~m}$ & 4 lajur & - & 0,45 \\
\hline $15,00 \mathrm{~m} \leq \mathrm{L}_{\mathrm{p}}<18,75 \mathrm{~m}$ & 5 lajur & - & 0,425 \\
\hline $18,75 \mathrm{~m} \leq \mathrm{L}_{\mathrm{p}}<22,00 \mathrm{~m}$ & 6 lajur & - & 0,4 \\
\hline
\end{tabular}
perkerasan dan koefisien distribusi (C) kendaraan niaga pada lajur rencana

b. Perhitungan repetisi sumbu yang terjadi

Tabel 4.14 Hasil Perhitungan repetisi sumbu yang terjadi 


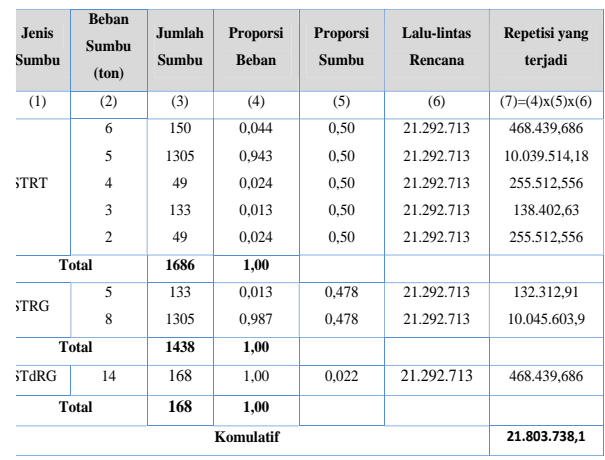

Perhitungan tebal pelat beton

$>$ Jenis perkerasan : BBTT dengan Ruji

$>$ Umur rencana $: 10$ th

> Jumlah Sumbu Kendaraan Rencana : 17.592.270

$>$ Faktor keamanan beban: 1,1

$>$ Kuat tarik lentur beton $\left(\mathrm{f}^{\prime}{ }_{\mathrm{cf}}\right): 3,4 \mathrm{Mpa}$

$>$ Jenis dan tebal lapis pondasi bawah : Bahan pengikat $10 \mathrm{~cm}$

$>$ CBR efektif : $8,2 \%$

$>$ Tebal taksiran pelat beton K-350:27 cm

> Tebal taksiran pondasi bawah : $10 \mathrm{~cm}$

Tabel 4.15 Analisa fatik dan erosi

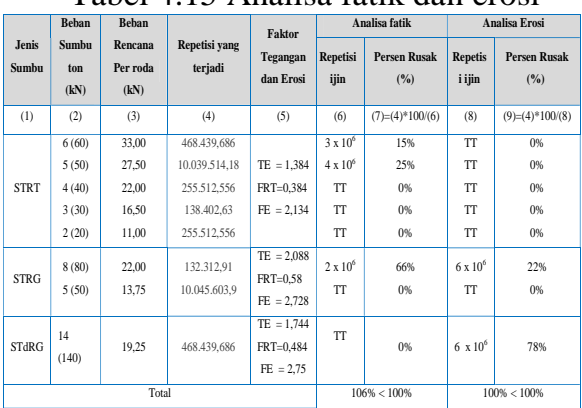

Keterangan :

$\mathrm{TE}=$ tegangan ekivalen; $\mathrm{FRT}=$ faktor rasio tegangan; FE = faktor erosi; TT = tidak terbatas

\section{9) Perhitungan Tulangan}

Perkerasan beton bersambung tanpa tulangan (BBTT).

- Tebal pelat

$$
: 27 \mathrm{~cm} \text {. }
$$

- Lebar pelat

$$
: 2 \times 3,5 \mathrm{~m}
$$

- Panjang pelat

$$
\text { : 5,0 m. }
$$

- Sambung susut dipasang setiap jarak 5 $\mathrm{m}$

- Ruji/dowel digunakan dengan $\varnothing 36 \mathrm{~mm}$, panjang $45 \mathrm{~cm}$, jarak $30 \mathrm{~cm}$

- Batang pengikat / Tie bar (i)

$=(38,3 \times \emptyset)+75 \mathrm{~mm}$

$=(38,3 \times 16)+75 \mathrm{~mm}$

$=687,8 \mathrm{~mm} \approx 700 \mathrm{~mm}(70 \mathrm{~cm})$

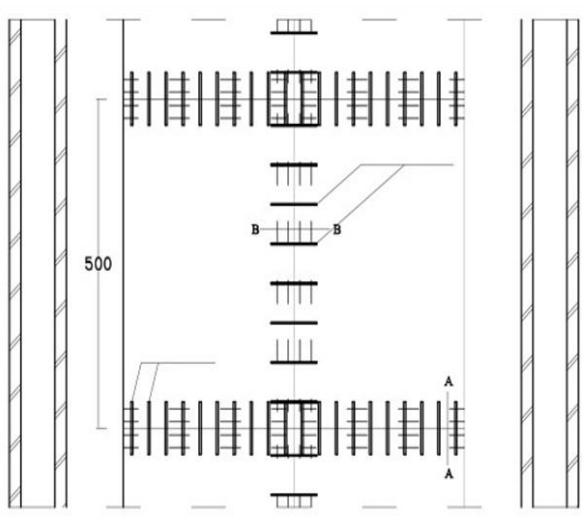

Gambar 4.16 Denah Dowel

10) Menetapkan Lapisan Perkerasan Lentur dan Perkerasan Kaku

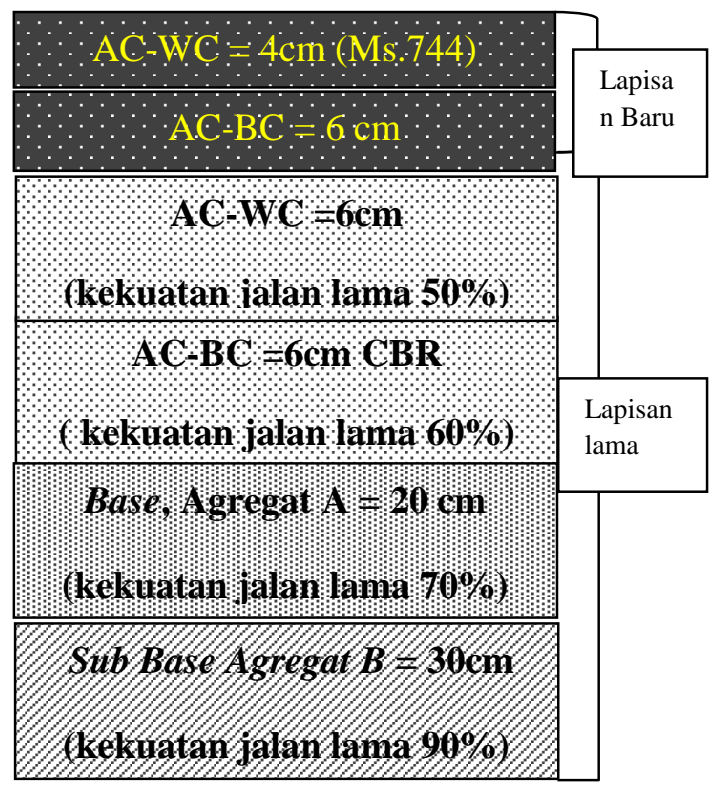

Gambar 4.17 Susunan Tebal Lapis Perkerasan Lentur 


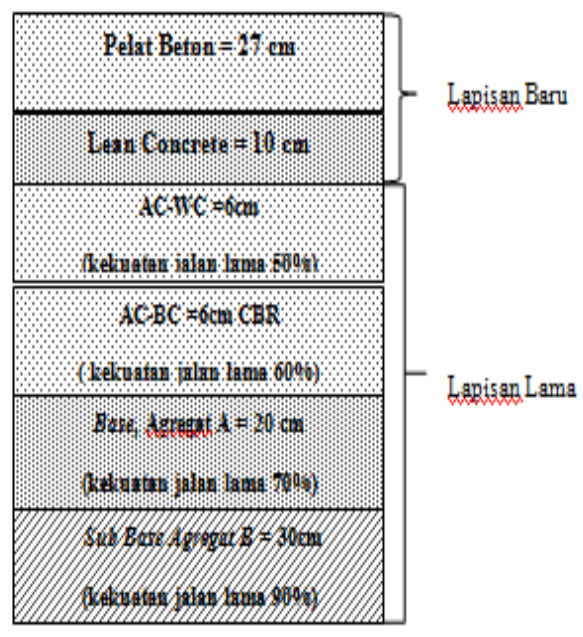

Gambar 4.18 Susunan Tebal Lapis Perkerasan Kaku

11) Rencana Anggaran Biaya Untuk Pekerjaan Perkerasan Lentur dan Perkerasan Kaku

Rencana Anggaran Biaya (RAB) suatu bangunan atau proyek adalah perhitungan banyaknya biaya yang diperlukan untuk bahan dan upah, serta biaya- biaya lain yang berhubungan dengan pelaksanaan bangunan atau proyek tersebut. Anggaran Biaya merupakan harga dari bangunan yang dihitung dengan teliti, cermat dan memenuhi syarat. Perhitungan rencana anggaran biaya pada ruas jalan Cianjur-Sukabumi SukabumiCiranjang dengan STA $67+720$ s/d 80+257 ditulis pada tabel 4.19 Rekapitulasi untuk pekerjaan perkerasan lentur, 4.20 Daftar kuantitas dan harga untuk pekerjaan perkerasan lentur, 4.21 Kurva S dan Bar Chat untuk pekerjaan pekerasan lentur, 4.22 Rekapitulasi untuk pekerjaan perkerasan kaku, 4.23 Daftar kuantitas dan harga untuk pekerjaan perkerasan kaku dan 4.24 Kurva $S$ dan Bar Chat untuk pekerjaan pekerasan kaku.

Tabel 4.19 Rekapitulasi pada pekerjaan perkerasan lentur

\begin{tabular}{|r|l|r|}
\hline No & \multicolumn{1}{|c|}{ Uraian } & $\begin{array}{c}\text { Jumlah Harga } \\
\text { Pekerjaan } \\
\text { (Rp) }\end{array}$ \\
\hline & & \\
\hline 1 & Umum & \\
\hline 2 & Drainase & 11.590 .220 \\
\hline 3 & & \\
\hline & Pekerjaan Tanah & 3.933 .462 .689 \\
\hline 4 & Pelebaran Perkerasann dan Bahu Jalan & \\
\hline & & 357.716 .854 \\
\hline 5 & Pekerjaan Perkerasa Berbutir & \\
\hline & & 2.725 .822 .450 \\
\hline 6 & Pekerjaan Aspal & \\
\hline & & 1.108 .796 .968 \\
\hline 7 & Pengmbalian Kondisi dan Pekerjaan Minor & \\
\hline (A) Jumlah Harga Pekerjaan (Termasuk Biaya Umum dan Keuntungan & 43.580 .793 .133 \\
\hline (B) Jumlah dibulatkan (A) & 43.580 .793 .200 \\
\hline (C) Pajak Pertambahan Nilai (PPN) = 10\% $\times$ (B) & 4.358 .079 .320 \\
\hline (D) Jumlah Total Harga Pekerjaan = (B) + (C) & 47.938 .872 .520 \\
\hline
\end{tabular}

Tabel 4.20 Daftar kuantitas dan harga untuk pekerjaan perkerasan lentur 


\begin{tabular}{|c|c|c|c|c|c|}
\hline $\begin{array}{c}\text { No. Nata } \\
\text { Pembayeran }\end{array}$ & Uraian & Satuan & \begin{tabular}{|l|} 
Perkiraan \\
Kuantitas
\end{tabular} & Harga satuan (Rp) & $\begin{array}{l}\text { Jumlah Harga- } \\
\text { harga }\left(\mathrm{R}_{\mathrm{p}}\right)\end{array}$ \\
\hline 1 & DIVISI 1.UMUM & & & & \\
\hline & Mobilisasi & Ls & & & \\
\hline \multicolumn{5}{|c|}{ Jumlah Harga Divisi 1 } & 11.590 .220 \\
\hline & DIVIS12.DRINASE & & & & \\
\hline \multirow[t]{2}{*}{2.1} & Pekejaan Gali inn Untuk Selokan & M3 & 7,000 & 126.791 & $887,540.138$ \\
\hline & Drainase dan Saluran air & & & & \\
\hline 2.2 & Pekejaan Pasangan Batu Dengan Mortar & M3 & 5.040 & 604,350 & $3.045,922551$ \\
\hline \multicolumn{5}{|c|}{ Jumlah Harga Divisi2 } & 3.933 .462689 \\
\hline & DIVISI 3-PEKERIAAN TANAH & & & & \\
\hline 3.1 & Galian Biasa & M3 & 1960 & 151.306 & 296.558 .789 \\
\hline 3.2 & Galian Perkerasan Beraspal & M3 & 420 & 145.614 & 61.158 .065 \\
\hline & Tanpa Cold Milling Machine & & & & \\
\hline \multicolumn{5}{|c|}{ Jumlah Harga Divisi } & 357.716 .854 \\
\hline & DVISI 4.PELEBARAN PERKERASAN & & & & \\
\hline & DAN BAHU IALAN & & & & \\
\hline 4.1 & Lapis Pondasi Agregat Kelas B & M3 & 4200 & 649.005 & 2.725 .822460 \\
\hline \multicolumn{5}{|c|}{ Jumlah Harga Divisic } & 2.725 .8222460 \\
\hline & DVIII 5.PERKERASAN BERBUTTR & & & & \\
\hline 5.1 & Lapis Pondasi Agregat Kelas A & MB & 1470 & 286.493 & 421.144 .927 \\
\hline 5.2 & Lapis Pondasi Agregat Kelas B & M3 & 1960 & 350.843 & 687,652041 \\
\hline \multicolumn{5}{|c|}{ Jumlah Harga Divisi I } & 1.108.796.968 \\
\hline & DIVISI 6-PERKERASAN ASPAL & & & & \\
\hline 6.1 & LapisResap Pengikat & Ltr & 980 & 59.992 & 58.791992 \\
\hline 6.2 & LapisPerekat & $L$ Ltr & 980 & 58.290 & 57.124 .481 \\
\hline 6.3 & Laston-Lapis Aus (AC-WC) & M2 & 98.000 & 221.301 & 21.687 .537 .740 \\
\hline 6.4 & Laston-Lapis Antara(AC-BC) & M3 & 5.880 & 1.294 .124 & 7.609 .499 .919 \\
\hline \multicolumn{5}{|c|}{ Jumlah Harga Divisie } & 29.412 .904 .131 \\
\hline & DIVIII7.PENGEMBALIAN KONDIII DAN & & & & \\
\hline & PEKERJAAN MINOR & & & & \\
\hline 7.1 & Lapis Pondasi Agregat Kelas AUntuk P.Mi & M3 & 1960 & 277.317 & $543,541,517$ \\
\hline 7.2 & Campuran Asaal Panas untuk P.Minor & M3 & 1960 & 2.604 .999 & 5.105 .797 .829 \\
\hline 7.3 & Marka Jalan Thermoplatic & M2 & 1750 & 217.806 & 381.160 .465 \\
\hline \multicolumn{5}{|c|}{ Jumlah Harga Divisiti } & 6.030 .499 .812 \\
\hline
\end{tabular}

Tabel 4.21 Kurva S dan Bar Chat untuk pekerjaan pekerasan lentur

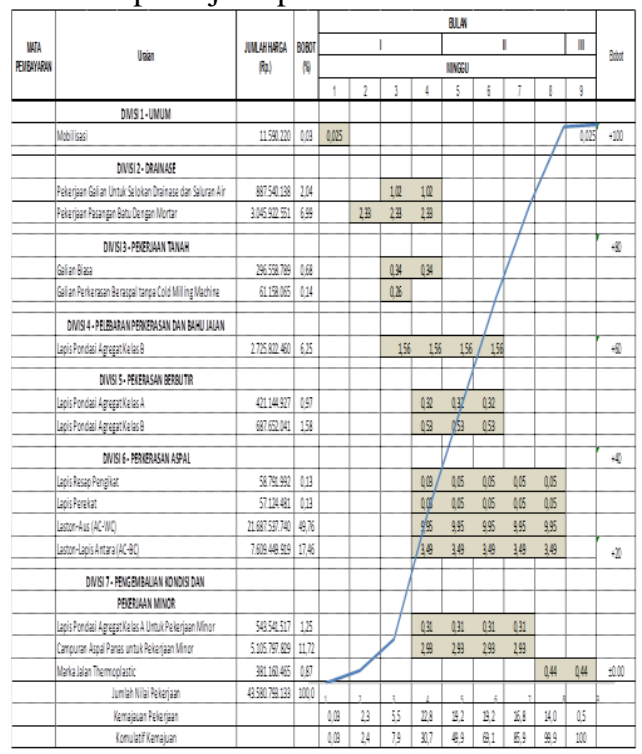

Tabel 4.22 rekapitulasi untuk pekerjaan perkerasan kaku

\begin{tabular}{|c|c|c|}
\hline & & Jumlah harge \\
\hline \multirow[t]{2}{*}{ No } & Uraian & Pekejazn \\
\hline & & $(\mathrm{Rop})$ \\
\hline & & \\
\hline & . & 116150 \\
\hline & 1 Unum & 11.61500 \\
\hline \multicolumn{2}{|r|}{2 Drinzse } & 3.94 .333 .034 \\
\hline & & \\
\hline \multicolumn{2}{|r|}{3 Pekrejazn Tarah } & 1.066 .97 .688 \\
\hline \multicolumn{2}{|r|}{ 4. Pelevaran Pekrerassndan Bahu Jalan } & 55.72 .42 \\
\hline \multirow{2}{*}{\multicolumn{2}{|c|}{5 Pekerjan Perkersa Beroutir }} & $67 \mathrm{mcm}$ \\
\hline & & $0 / 1 / .045 .30 /$ \\
\hline \multicolumn{2}{|r|}{6 Strukur } & 2.578 .999 .96 \\
\hline \multicolumn{2}{|r|}{7 Pengngalian Kondsi dan Pekerjan Ninor } & 611.050 .778 \\
\hline \multicolumn{2}{|c|}{ 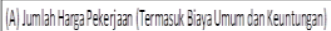 } & 59.412 .73 .817 \\
\hline \multicolumn{2}{|c|}{ (B) Jumlandibulatitan (A) } & 59,42.754,900 \\
\hline \multicolumn{2}{|c|}{ 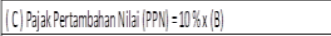 } & $5,94.255 .490$ \\
\hline \multicolumn{2}{|c|}{ (D) Jumlah Total hagra Pekerizan = (B) + (C) } & 66.354 .020 .390 \\
\hline
\end{tabular}

Tabel. 4.23 Daftar kuantitas dan harga untuk pekerjaan perkerasan kaku

\begin{tabular}{|c|c|c|c|c|c|}
\hline $\begin{array}{l}\text { No.Mata } \\
\text { Pembayaran }\end{array}$ & Uraian & Satuan & $\begin{array}{l}\text { Perkiran } \\
\text { Kuantitas }\end{array}$ & Hargas satuan $\left.\left(R_{p}\right)\right]$ & $\begin{array}{c}\text { Jumlah Harga- } \\
\text { hargaga (Rp) }\end{array}$ \\
\hline & & & Segmen 1 & Segmen 1 & Segmen 1 \\
\hline & DIIS1.UMUM & & & & \\
\hline & Mobilissai & Ls & & & 11.611 .500 \\
\hline \multicolumn{5}{|c|}{ Jumlah Harga Divisis } & 11611.500 \\
\hline & DIVIII2-DRINASE & & & & \\
\hline & Pekerjazn Galian Untuk Selokan & MB & 7000 & 127916 & $895,410.483$ \\
\hline & Drainase dan Saluran air & & & & \\
\hline & Pekerjazan Pasangan Batu Dengan Mortar & M3 & 5040 & 604350 & 3.045 .922 .551 \\
\hline \multicolumn{5}{|c|}{ Jumlah Harga Divisi2 } & 3.941333 .034 \\
\hline & DIVISI 3.PEKERAANTANAH & & & & \\
\hline & Galian Biasa & MB & 1950 & 172.531 & 338.161 .477 \\
\hline \multicolumn{5}{|c|}{ Jumlah Harga Divisi3 } & 338.161 .477 \\
\hline & DIVIS 4.PELEBARAN PERKERASAN & & & & \\
\hline & DANBAHUJALAN & & & & \\
\hline & Lapis Pondasi Agregat Kelas B & MB & 4200 & 120.408 & 505.712 .432 \\
\hline \multicolumn{6}{|c|}{ Jumlah Harga Divisia } \\
\hline & DVISI 5.PERKERASAN BERBUTIR & & & & \\
\hline & Lapis Pondasi Agregat Kelas B & MB & 1950 & 345.459 & 677.099 .507 \\
\hline \multicolumn{5}{|c|}{ Jumlah Harga Divisis } & 677.099 .507 \\
\hline & DIVISIGSTRUKTUR & & & & \\
\hline & Beton K-350 & MB & 26.460 & 1.003 .287 & 42.422.961.74 \\
\hline & Wet Leen Conrete & MB & 9.800 & 1.036 .330 & 10.1560.038.189 \\
\hline \multicolumn{5}{|c|}{ Jumlah Harga Divisici6 } & 52.5789999 .963 \\
\hline & DNISI 7.PENGEMBALLAN KONDSI DAN & & & & \\
\hline & PEKERAAN MINOR & & & & \\
\hline & Gal lan untuk Bahu Jalan dan P. Mior lànnya & MB & 1950 & 117.291 & 229.890 .313 \\
\hline & Marka Jalan Them opplatic & M2 & 1.750 & 217.806 & 381.1600 .465 \\
\hline \multicolumn{5}{|c|}{ Jumlah Harga Divivisi } & 611050,778 \\
\hline
\end{tabular}

Tabel 4.24 Kurva S dan Bar Chat untuk pekerjaan pekerasan kaku 


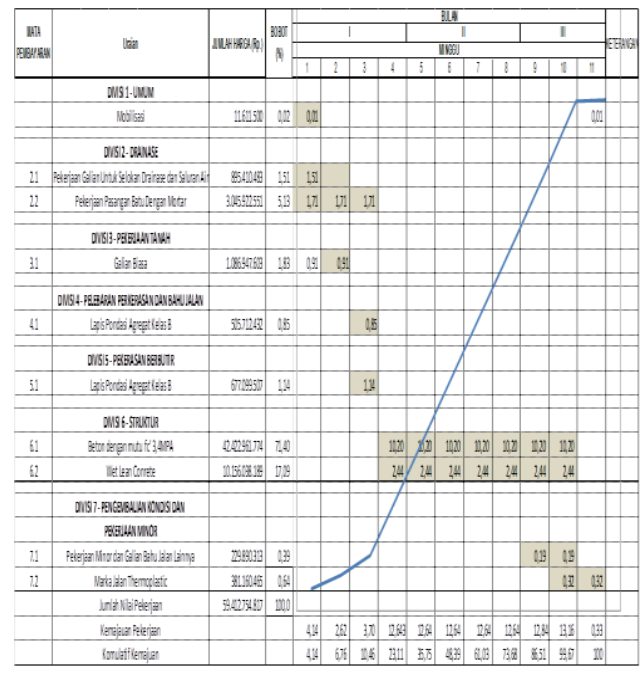

Hasil perhitungan untuk pekerjaan perkerasaan lentur didapat overlay Asphalt concrete AC-WC $(\mathrm{MS} .744)=4 \mathrm{~cm}, A C-B C$ $=6 \mathrm{~cm}$ dengan data pendukung $2 / 2 \mathrm{UD}$, data lalu lintas 7405 kend/hari, umur rencana 10tahun, pertubuhan lalu lintas kendaraan ringan dan truck 2 as $15 \%$ sedangkan untuk bus, truck 3as, an truck gandeng 8\%, FR 1,0, kelandaian jalan 5\%, curah hujan 405 $\mathrm{mm} / \mathrm{tahun}$, CBR 3\%, DDT 3,8\%, Ipt 2,5, IPo 3,9, LER 1258. Dan untuk hasil pekerjaan perkerasan kaku,

\section{Kesimpulan}

1. Hasil perhitugan perkerasan lentur untuk ruas jalan Cinjur-Sukabumi dengan Km.Bdg 67+720 s/d 80+257 di dapat overlay $4 \mathrm{~cm} A C-W C$, dan $6 \mathrm{~cm}$ untuk $A C-B C$.

2. Untuk nilai CBR didapat sebesar $=3 \%$. Nilai CBR tersebut merupakan nilai CBR rencana, sehingga untuk CBR efektifnya didapat sebesar $8,2 \%$ (didapat dengan cara grafis).

3. Untuk hasil perhitungan tebal perkerasan kaku yaitu sebesar $27 \mathrm{~cm}$, ketebalan yang didapatkan untuk pekerasan kaku sesuai peraturan provinsi Jawa Barat.

4. Hasil perhitungan untuk rencana anggaran biaya pada pekerjaan perkerasan lentur di dapat sebesar $\mathrm{Rp}$ 43.580.793,133 sedangkan untuk perkerasan kaku di dapat Rp 59.412.754.817.

\section{DAFTAR PUSTAKA}

SNI (2016) Analisa Satuan Harga Provisi Jawa Barat.

SNI Pd T-14-2003 Departemen Pekerjaan Umum, Perencanaan Jalan Beton Semen.

No. KM 55 Tahun (1989) Kemen Perhubungan

Pekerjaan Umum SNI1732-1989-F (1987) Perencanaan Tebal Perkerasan Lentur Jalan Raya dengan Metode Analisa Komponen.

No.34 (2006) Peratutan Tentang Jalan.

Peraturan Pelaksanaan Pembangunan Jalan Raya-Bina Marga.

Sony Sulaksono (2001) Rekayasa Jal 
